\title{
Stefan Gajda
}

PAN Katowice

\section{Cieszyńskie wspomnienia}

Informacje redaktora naczelnego o przygotowaniach do wydania kolejnego tomu „Górnośląskich Studiów Socjologicznych”, tomu poświęconemu Cieszynowi, i prośba o podzielenie się moimi doświadczeniami ze współpracy i kontaktami z przedstawicielami ziemi cieszyńskiej przyczyniły się do krótkiego przedstawienia moich wspomnień i różnych form działalności. Postaram się na bazie własnych doświadczeń, nie tylko zawodowych, pokazać w formie informacyjnej wydarzenia z zakresu działalności zawodowej, społecznej i czasu studiów.

Ponad 40-letnia praca w Oddziale Polskiej Akademii Nauk w Katowicach umożliwiła mi nawiązanie wielu różnorodnych kontaktów ze środowiskami naukowymi i ośrodkami uczelnianymi. Te liczne kontakty przypomniały mi również fakt wydania w 1989 roku ostatniego tomu „Studiów Socjologicznych”, pod redakcją prof. Jacka Wodza, który — podobnie jak obecny redaktor tomu prof. Wojciech Świątkiewicz - był moim dyrektorem w Śląskim Instytucie Naukowym w Katowicach. Stąd też moje wspomnienia, najczęściej bardzo osobiste i emocjonalne.

Pierwsze moje kontakty z Cieszynem przypadły na połowę lat 70 . ubiegłego wieku. Wtedy rozpocząłem studia w Filii Uniwersytetu Śląskiego. Okazały budynek Studium Nauczycielskiego, dwa akademiki w pobliżu i piękne otoczenie tworzyły urokliwą przestrzeń, dzisiaj zwaną kampusem. W ówczesnym okresie nie wszyscy potrafili docenić zalety tej infrastruktury. W pierwszych latach działalności Filii US, oprócz kierunków filologia polska i historia, utworzono także kierunki pedagogika pracy kulturalno-oświatowej, wychowanie muzyczne i wychowanie plastyczne. Studenci, w liczbie około 500, mieszkali głównie w akademikach, a klub Panopticum i radiowęzeł zapewniały miłe spędzanie wolnego czasu. Studenci kierunków artystycznych, dotyczyło to zwłaszcza plastyków, dodawali kolorytu uczelni. Znany i funkcjonujący do dzisiaj chór Harmonia, chluba Uniwersytetu Śląskiego, po powrocie z każdego występu, wysiadając z autokaru, śpiewał przed akademikiem pieśn Rycerze. Wiedzieliśmy wtedy, że wraca nasz chór. Podobnie spontanicznie reagowali 
studenci wychowania muzycznego - gdy Konkurs Chopinowski wygrał Krystian Zimerman, trójka studentów, grając na trąbkach, fetowała ten sukces polskiego pianisty, a należy zaznaczyć, że było to już grubo po godzinie 22 , a może nawet po północy.

Myślę, że tak jak w wielu ośrodkach akademickich również i w Cieszynie studenci mieli swoje przyzwyczajenia do odwiedzania pewnych miejsc. Jednym z nich dla części studentów wtedy Fili UŚ był tzw. Kopiec. Tam, oprócz okolicznych wozaków, można było się uraczyć piwem, a zdarzało się, że przenoszono je do akademika w... kloszach; pomysł ten nie zawsze był akceptowany przez władze uczelni.

Organizacja życia na uczelni stwarzała pogodną atmosferę, powodowała, że panowała w niej niewymuszona serdeczność w stosunku do bardzo wielu osób. Dotyczyło to zarówno pracowników naukowych, jak i pracowników administracji i obsługi. Również wystrój uczelni - gdzie prezentowane były prace artystyczne studentów kierunku wychowanie plastyczne i gdzie słyszało się ćwiczenia studentów wychowania muzycznego - powodował, że mile spędzało się tam czas. Tak też jest do dzisiaj, chociaż uczelnia rozbudowała się i przez kolejne lata zmieniała profil kształcenia. Były też organizowane, głównie przez samorząd studencki, pożegnania roczników kończących studia; coś się kończyło, ale starano się zachować ciągłość i pamięć o tych, którzy odchodzą. W spotkaniach tych w klubie Panopticum uczestniczyli zarówno studenci, jak i pracownicy naukowi.

Ponieważ od początku studiów zaangażowałem się w prace samorządu studenckiego, moje kontakty z wieloma osobami, nie tylko spośród władz uczelni, stały się jeszcze bliższe. Reprezentując studentów, często uczestniczyłem w rozmowach zarówno z prorektorem, Antonim Gładyszem, jak i dziekanami. Sądzę, że jako środowisko studenckie nadawaliśmy kolorytu Cieszynowi. Corocznie w maju były przez nas organizowane „Cieszynalia” — przejęcie na balkonie Urzędu Miasta symbolicznego klucza na władanie miastem przez studentów, korowód żaków, liczne imprezy kulturalne w mieście i na uczelni były okazją do pokazania mieszkańcom potencjału braci studenckiej. Wiele zakładów pracy i instytucji wspierało „Cieszynalia”, zawsze też były wspomagane rzeczowo przez okoliczny browar. Nawet w okresie wakacji uczelnia nie wyludniała się. Organizowano różne znaczące imprezy kulturalne, m.in. Festiwal Studentów Szkół Artystycznych, przez kilka lat działał też Międzynarodowy Hotel Studencki i tak jest chyba do dzisiaj.

Wspominając okres studiów, pragnę zwrócić uwagę na rzecz już wtedy przeze mnie docenianą — na identyfikację ze środowiskiem, grupą, regionem, w którym się znajdujemy. Do dziś wspominam dyrektora administracyjnego, który w znaczący sposób przyczynił się do rozwoju uczelni, a jednocześnie wykazywał wyjątkową dbałość o estetykę otoczenia. Przytoczę następujący przykład: kiedy my studenci zostawialiśmy płaszcze czy kurtki na stolikach w holu naprzeciw gabinetu rektora, dyrektor Zbigniew Gąszczyk zabierał je do swojego gabinetu i przy odbiorze informował, po co na uczelni jest szatnia. Rzecz może błaha, ale jak

278 się okazało na jednym z rocznicowych spotkań, wiele osób dokładnie zapamiętało 
to zachowanie. Wśród studentów była również grupa Polaków z Zaolzia — to w ich pokojach w akademiku można się było zajadać orzeszkami arachidowymi i lentilkami, towarem z zagranicy, który nie był wtedy dostępny tak jak dzisiaj. Okres studiów to czas poznawania bardzo wielu wartościowych ludzi, z którymi miałem przyjemność współpracować w czasie swojej działalności zawodowej w Oddziale PAN w Katowicach i w innych przedsięwzięciach.

Warto przypomnieć, że 3 marca 1992 roku prof. Adolf Dygacz skierował pismo do Prezydium Oddziału PAN w Katowicach z prośbą o powołanie Komisji ds. Stosunków Polsko-Czeskich na Śląsku Cieszyńskim. Komisja miała mieć charakter interdyscyplinarny i skupiać osoby zajmujące się naukowo wzajemnym oddziaływaniem kultury polskiej i czeskiej w częściach Śląska rozdzielonych granicą. Wniosek został poparty przez prof. Jana Kubika, dzięki czemu można było przystąpić do prac nad powołaniem komisji integrującej całokształt problematyki badawczej związanej z sąsiedztwem polsko-czeskim na Zaolziu. W dniu 25 czerwca 1992 roku Prezydium Oddziału PAN w Katowicach uchwaliło powołanie Komisji ds. Stosunków Polsko-Czeskich i Polsko-Słowackich. Powołane też zostało prezydium Komisji w składzie: przewodniczący Alojzy Kopoczek, zastępcy Kazimierz Ślęczka, Edmund Rosner, Krystyna Turek, sekretarz Joachim Liszka; komisja liczyła 25 członków. W 1995 roku, z inicjatywy Prezydium Oddziału PAN, uzyskano zgodę Prezesa PAN Leszka Kuźnickiego na rozszerzenie składu Komisji o członków z Czech i Słowacji. Otrzymali oni statut wspótpracowników Komisji Oddziału PAN w Katowicach. Kolejnymi przewodniczącymi Komisji byli: Edmund Rosner, Zygmunt Kłodnicki, Wiesława Korzeniowska, Józef Budniak, Andrzej Murzyn, a od roku 2015 do teraz jest nim Wojciech Świątkiewicz. Komisja nawiązała liczne kontakty krajowe i zagraniczne, ściśle związane ze swoją działalnością, m.in. z: Wydziałem Filozoficznym Uniwersytetu Preszowskiego w Preszowie, Zakładem Historii Nowożytnej i Współczesnej Instytutu Filozofii UŚ, Uniwersytetem im. Cyryla i Metodego w Nitrze, Uniwersytetem im. Mateja Bela w Bańskiej Bystrzycy, Uniwersytetami w Pradze, Ostrawie, Opawie, Bratysławie i Ołomuńcu. Bieżąca działalność Komisji to organizowanie posiedzeń mających otwarty charakter i dotyczących problematyki tradycji kulturowej terenów przygranicznych polsko-czeskich i polsko-słowackich.

O postrzeganiu Komisji i jej roli w inspirowaniu działań w terenie przygranicznym wobec nowych wyzwań współpracy transgranicznej oraz nowych zadań i problemów w Europie Środkowej mówiono podczas konferencji jubileuszowej z okazji 25-lecia pracy Komisji (5 czerwca 2017 roku). W tym bardzo miłym spotkaniu uczestniczyły osoby działające w Komisji, jak również jej członkowie założyciele. Historia, teraźniejszość i przyszłość były tematem panelu dyskusyjnego. Spotkanie jubileuszowe Komisji przebiegało w bardzo przyjaznej, prawie rodzinnej atmosferze. O doniosłości wydarzenia przypomniał wystrój Sali Senackiej, który nie zmienił się od drugiej połowy lat 70. ubiegłego wieku; te same krzesła i stoły, podobnie jak wtedy, tak i dzisiaj tworzą klimat Sali i całego budynku. Wtedy też była okazja do zaprezentowania osiągnięć Komisji w zakresie organizacji konferencji czy wydawnictw. Przedstawię tylko kilka wybranych — tych, które może 
w znaczniejszy sposób związane są z Cieszynem, a o których wspominano na uroczystości jubileuszu Komisji.

W 2005 roku Komisja była współorganizatorem konferencji pt. „Aby byli jedno" z okazji 10-lecia wydania encykliki Jana Pawła II (Ut unum sint). W roku 2018 zorganizowano w klasztorze bonifratrów w Cieszynie konferencję naukową pt. „Dziedzictwo kulturowe Apostołów Słowian na Śląsku”. Spotkanie, w którym udział wzięli m.in. duchowni katoliccy, protestanccy i prawosławni, naukowcy z Polski, Słowacji i Czech, samorządowcy i przedstawiciele administracji publicznej, zorganizowano z okazji 1150. rocznicy śmierci św. Cyryla i 400. rocznicy śmierci męczeńskiej św. Melchiora Grodzieckiego — urodzonego w Cieszynie, a którego Sejmik Województwa Śląskiego ogłosił patronem 2019 roku.

Komisja bierze aktywny udział w międzynarodowych projektach badawczych, m.in. w projekcie badawczym w ramach Międzynarodowego Funduszu Wyszehradzkiego przy współpracy z zespołami badawczymi z uniwersytetów z Nitry, Hradec Králové, Szeged i Katowic. Inicjatywą wydawniczą było objęcie patronatem honorowym, wraz z Rektorem Uniwersytetu Śląskiego prof. dr. hab. Januszem Janeczkiem oraz Międzynarodową Wspólnotą Ekumeniczną Region Polski, międzynarodowej serii wydawniczej „Dialog bez granic”. Współpraca Komisji ze Stowarzyszeniem Rozwoju i Współpracy Regionalnej „Olza” zaowocowała prezentacją serii TRANSCARPATHICA, a prof. dr hab. Andrzej Kasperek, jako redaktor serii i badacz tożsamości regionalnej, zapewnił, że problematyka transgraniczna będzie podejmowana w kolejnych tomach.

Tematykę relacji przygranicznych porusza praca dr hab. Mirosławy Pindur pt. Polsko-czeskie i polsko-słowackie kontakty teatralne. Cieszyn-Czeski Cieszyn 1945-1999 (wydana w 2004 roku).

Pod patronatem Komisji ukazały się również m.in. takie publikacje jak Polska - Czechy - Słowacja. Oblicza religijności (praca zbiorowa pod redakcją Józefa Budniaka i Andrzeja Kasperka, 2011) oraz Intelektualne i duchowe dziedzictwo Cyryla i Metodego. Historia i aktualność tradycji cyrylo-metodiańskiej (praca zbiorowa pod redakcją Józefa Budniaka i Andrzeja Kasperka, 2014).

W roku 2019 z okazji jubileuszu 10-lecia Wydziału Zamiejscowego w Cieszynie, połączonego z uroczystą Inauguracją Instytutu Studiów nad Współpracą Terytorialną i Międzyorganizacyjną podpisano listy intencyjne o współpracy Instytutu Studiów nad Współpracą Terytorialną i Międzyorganizacyjną Akademii WSB w Wydziale Zamiejscowym w Cieszynie z dwoma strategicznymi partnerami naukowymi: Komisją ds. Stosunków Polsko-Czeskich i Polsko-Słowackich Oddziału PAN oraz Siecią EuroInstytutu Polsko-Czesko-Słowackiego z siedzibą w Cieszynie. W imieniu Komisji podpis pod listem intencyjnym złożył prof. dr hab. Wojciech Świątkiewicz, Przewodniczący Komisji. W imieniu sieci EuroInstytutu Polsko-Czesko-Słowackiego z siedzibą w Cieszynie, w imieniu którego działa Stowarzyszenie Rozwoju i Współpracy Regionalnej „Olza”, podpisy pod listem intencyjnym złożyli Janusz Pierzyna - Wójt Jasienicy, Prezes Zarządu Stowarzyszenia i Bogdan Kasperek - Dyrektor Biura Stowarzyszenia, Przewodniczący

280 Rady Programowej EuroInstytutu Polsko-Czesko-Słowackiego. W imieniu Aka- 
demii WSB podpisy pod listami intencyjnymi złożyła dr Joanna Kurowska-Pysz, Dyrektor Instytutu Studiów nad Współpracą Terytorialną i Międzyorganizacyjną Akademii WSB w Wydziale Zamiejscowym w Cieszynie. Jak widać, działalność Komisji jest wysoko oceniana w środowisku naukowym nie tylko krajowym, ale i poza granicami.

Dobrze, że członkowie Komisji zadbali o to, aby działalność Komisji była widoczna również w gablocie na I piętrze uczelni, gdzie prezentowane są wydawnictwa i bieżące informacje.

Nie tylko praca zawodowa powodowała, że moje kontakty z Cieszynem i uczelnią rozwijały się na płaszczyźnie działalności społecznej. Kiedy w roku 1991 w Katowicach powołany został Górnośląski Oddział Stowarzyszenia „Wspólnota Polska", celem jego działania było dotarcie do środowisk polskich i polonijnych poza krajem, do środowisk potrzebujących pomocy w organizowaniu i odradzaniu swojej tożsamości w miejscach swego zamieszkania. Za priorytetowe kierunki działalności przyjęto zadania oświatowo-edukacyjne, wspieranie kultury i tradycji polskiej i polonijnej. Ze względu na lokalizację Oddziału naturalną formą jego działań było i jest wspomaganie społeczności polskiej na Zaolziu. Podjęto szereg kontaktów z organizacjami polskimi na Zaolziu, a w Cieszynie nawiązano niezapomniany kontakt i przeprowadzono wiele rozmów z Panem Władysławem Oszeldą, założycielem i liderem Klubu Propozycji, jednym z członków przedwojennej polonijnej organizacji Światpol. Migracja ludności w jednoczącej się Europie i zachodzące zmiany w postrzeganiu, szczególnie przez najmłodsze pokolenie, własnej tożsamości, korzeni własnej kultury zainspirowało Górnośląski Oddział do zorganizowania corocznego konkursu gwar „Po cieszyńsku po obu stronach Olzy”. Konkurs organizowany jest wspólnie z Polskim Związkiem Kulturalno-Oświatowym w Republice Czeskiej, przy wydatnej pomocy kolejnych Burmistrzów Cieszyna i współpracy z Domem Narodowym, który organizuje przesłuchania i koncerty. Od 2004 roku odbyło się już 16 edycji konkursu, w których uczestniczyło 2500 uczniów i przedszkolaków z 35 placówek oświaty i kultury ziemi cieszyńskiej i Zaolzia. Eliminacje i koncert finałowy to wielkie przeżycie dla dzieci — a może, jak należy powiedzieć, ,dziecek” — a także dla ich opiekunów i rodziców. Nie tylko umiejętność posługiwania się gwarą, lecz także zwracanie uwagi na odpowiedni strój i częste korzystanie z tekstów pisanych przez „starki i starzyków" co roku jest doceniane przez jurorów konkursu. A wszystkim organizatorom i uczestnikom pokazuje wielkie zaangażowanie ludzi młodych w kultywowanie tradycji i poszukiwanie korzeni i tożsamości w swojej Małej Ojczyźnie.

Od prawie 30 lat Górnośląski Oddział Wspólnoty Polskiej, którym kieruję, związany jest z Letnią Szkołą Języka Literatury i Kultury Polskiej Uniwersytetu Śląskiego; wszystkie miesięczne turnusy odbywały się w Cieszynie w kampusie uniwersyteckim. I znowu urok tego miejsca, akademik, sale wykładowe, stołówka, stała możliwość kontaktu między sobą i wykładowcami powodowały, że wszyscy uczestnicy Szkoły cały czas mieli możliwość bycia ze sobą i uczenia się języka polskiego. Uczestniczyłem w ponad 20 inauguracjach Szkoły Języka Polskiego. Różnorodność uczestników, docierających z tak wielu krajów całego świata, napawa 
optymizmem, że chcą oni poznać nasz region i uczyć się języka polskiego. Z roku na rok przybywała coraz liczniejsza grupa uczestników; w pierwszych latach mogli oni przedstawiać się w czasie inauguracji indywidualnie, a już w latach następnych organizatorzy przedstawiali się grupowo z państw, które reprezentowali, tak wielu było uczestników. Pierwsze inauguracje Letniej Szkoły odbywały się w budynku uczelni, w sali, która kiedyś pełniła funkcję sali gimnastycznej, a z czasem została zamieniona na w pełni profesjonalną salę audiowizualną. Po inauguracji uczestnicy Szkoły szli w grupach zwiedzać Cieszyn. Ja sam również często szedłem — przypomnieć sobie to miasto.

Pragnę także podkreślić, że i w czasach studenckich, i obecnie Cieszyn jest dla mnie miastem bardzo urokliwym - z brukowanymi, wąskimi, spadającymi w dół uliczkami, zabytkami, kamieniczkami, arkadami, hotelem Pod Jeleniem oraz Rynkiem. Chociaż był wtedy trochę zbyt spokojny i sprawiał wrażenie wyciszonego. Patrząc z perspektywy lat 70., spostrzegam, że nadal, tak jak wtedy, w maju kwitną piękne magnolie; żeby pozwiedzać urokliwe zakątki, trzeba nachodzić się to w górę, to w dół, a Olza płynie spokojnie, chociaż już nie dzieli, tylko łączy. Szkoda, że przy granicy zniknął sklep ze słodyczami „Olza”. Za to kilkadziesiąt metrów za granicą mamy Avion, przybytek kultury polskiej i czeskiej, w którym miało miejsce pewne wydarzenie - z okazji 200. rocznicy urodzin Fryderyka Chopina Oddział Wspólnoty Polskiej zorganizował prezentację pt. „Muzyka Chopina w obrazach Dudy Gracza".

Chodząc po dzisiejszym Cieszynie, podobnie jak kilka lat wcześniej, chodzę na Wzgórze Zamkowe pod Rotundę, uwidocznioną na banknocie 20-złotowym, patrzę na Olzę, która coraz częściej jest bardzo płytka i płynie sobie wolno. $Z$ okolic Wieży Piastowskiej spoglądam na panoramę Cieszyna i Czeskiego Cieszyna, kieruję się w stronę Cieszyńskiej Wenecji i na ulicę Głęboką, bardzo urokliwą i pełną turystów. Moje oko, i sądzę, że oczy wielu przechodniów zawsze przyciągają prezentowane $\mathrm{w}$ witrynach sklepów tzw. tableaux z wizerunkami ,absolwentów cieszyńskich szkół średnich wraz z kadrą pedagogiczną". I chociaż jest coraz mniej tych zbiorowych fotografii, zawsze z chęcią je oglądam, szukając znajomych nazwisk dzieci, a może już wnuków osób, które znałem z Cieszyna i okolic. I może dawniej zdjęcia te oglądane były z większym zainteresowaniem i dumą niż dzisiaj w dobie Internetu, gdzie nasza obecność jest często niestała i bezosobowa.

Te krótkie wspomnienia powinny być zapewne poszerzone o przedstawienie z imienia i nazwiska bardzo dużej grupy osób, ważnych dla miasta i lokalnej społeczności. Myślę, że przyglądając się wszystkiemu temu, co dzieje się w Cieszynie, mamy szansę na poznawanie coraz to nowszych osób i wielu wydarzeń ważnych dla tego miasta.

I tak jak gdzieś kiedyś przeczytałem: „Kto raz był w Cieszynie, już będzie tęsknić do jego uroku" - potwierdzam to z pełną atencją i szacunkiem dla jego historii i dnia dzisiejszego, a los niech da mi jak najczęściej tam bywać. 